\title{
Moroccan Teachers' Level of ICT Integration in Secondary EFL Classrooms
}

\author{
Yassine Ait Hammou \\ EFL teacher/Ph.D. candidate, Ibn Zohr university, Morocco \\ yassine.aithammou@edu.uiz.ac.ma \\ Mohamed Elfatihi \\ Associate professor of applied linguistics Ibn Zohr university, Morocco \\ elfatihimohamed@gmail.com
}

DOI:https://doi.org/10.36892/ijlls.v1i3.65

\begin{tabular}{|c|c|}
\hline $\begin{array}{l}\text { Received: } \\
\text { 10/10/2019 }\end{array}$ & $\begin{array}{l}\text { Abstract } \\
\text { The sheer growth of information and communication technologies (ICT) has }\end{array}$ \\
\hline $\begin{array}{l}\text { Accepted: } \\
\text { 26/11/2019 }\end{array}$ & $\begin{array}{l}\text { reshaped teaching and learning practices tremendously in the learning } \\
\text { environments all over the globe. Research reveals that teachers are the key } \\
\text { agents in the integration of ICT in particular in language teaching and } \\
\text { learning. However, some of the many factors, this ICT integration are }\end{array}$ \\
\hline $\begin{array}{l}\text { Keywords: } \\
\text { ICT; Educational } \\
\text { Technology; EFL; } \\
\text { Moroccan ELT }\end{array}$ & $\begin{array}{l}\text { associated with teachers' personal characteristics such as gender. Therefore, } \\
\text { the current study investigates the Moroccan male and female teachers' level of } \\
\text { ICT integration in teaching English as a foreign language (EFL) in the public } \\
\text { secondary school EFL classrooms. This study aims to explore whether gender } \\
\text { influences the way EFL teachers' ICT use in the classroom. It is a survey } \\
\text { which adopts a mixed-method approach of investigation, and two instruments } \\
\text { are used to collect data: a questionnaire and a semi-structured interview. } \\
\text { Eighty full-time teachers (45 male and } 35 \text { female teachers) belonging to } \\
\text { different public secondary schools in the area of Agadir Idaoutanane and } \\
\text { Inzegane Ait-Meloul participated in the study by answering a questionnaire, } \\
\text { and eight teachers out of this sample (4 male and } 4 \text { female teachers) are } \\
\text { interviewed. The results of data analysis reveal that although female teachers } \\
\text { employed ICT in their teaching less than their male counterparts, there is no } \\
\text { significant difference in using ICT in language teaching between the two } \\
\text { groups. A number of propositions are presented as to how to incorporate ICT } \\
\text { in language learning in the Moroccan secondary schools EFL contexts. }\end{array}$ \\
\hline
\end{tabular}

\section{INTRODUCTION}

ICT in education has created a number of opportunities for language learning, more specifically in the ELT, ESL and EFL settings. Not only does it accelerate, facilitate, enrich and enhance the teaching and learning of basic language skills, but it does also help students become quick learners in an easy manner at any time, and anywhere. It also allows learners to get into a more productive learning and working environment than it was the case previously. However, teachers now face more challenges when attempting to make use of ICT than before (Keengwe, Onchwari, \& Wachira, 2008).

The absolute presence of ICT in the educational settings has opened a new trend of investigation into the issue of teaching and learning effectiveness. Generally speaking, findings from previous research on the impact of ICT on education supports the fact that ICT makes it possible to improve teaching and learning environments (Hermans, Tondeur, van Braak, \& Valcke, 2008; Abu Elenein, 2019) and can positively affect students' learning (Cancannon, Flynn, \& Campbell, 2005), motivation (Mahdizadeh, Biemans, \& Mulder, 
2008), critical thinking (Lim, Teo, Wong, Khine, Chai, \& Divaharan, 2003), and autonomy (Claudia, Steil, \& Todesco, 2004).

Nevertheless, a number of aspects determine the success or failure of the incorporation of ICT in language teaching. As a result, studies investigating these factors, have started to proliferate recently in different countries (e.g., Baylor \& Ritchie, 2002; Granger, Morbey, Lotherington, Owston, \& Wideman, 2002; Robinson, 2003; Hew \& Brush, 2007; Hermans et al., 2008; Paraskeva, Bouta, \& Papagianni, 2008; Kim, Jung, \& Lee, 2008; Inan \& Lowther, 2010; Zamani, 2010). The teachers' views and perceptions of the use of ICT in language learning and teacher training have been the main focus of many studies (Chen, 2008; Egbert, Paulus \& Nakamichi, 2002; Hubbard, 2008; Park \& Son, 2009; Russell \& Bradley, 1997). However, teachers' personal characteristics such as age, working experience, and gender are some of the other factors that affect the integration of ICT into language teaching and learning. These factors have been probed by few research studies (Egbert, Paulus \& Nakamichi, 2002; Teo, 2008; Todman, 2000; Yaghi, 2001). In this regard, different conclusions have been drawn regarding the factor of gender as two conflicted results are conveyed in prior studies about the effect of teachers' sex on ICT use in the classroom. One showed that teachers' gender influences the use of ICT in language teaching and learning, but the other found that teacher gender had no impact.

\section{Gender factor and classroom ICT use}

Teachers' personal characteristics and demographic variables have been researched by numerous studies that have focused on exploring the role of teachers' age, gender, and years of teaching experience in their ICT integration in the classroom (e.g., Robinson, 2003; Van Braak, Tondeur, \& Valcke, 2004; Bebell, Russell, \& O’Dwyer, 2004; Egbert, Paulus \& Nakamichi, 2002; Teo, 2008; Todman, 2000; Yaghi, 2001). As regards gender, different results emerged from these studies about the effect of teachers' gender on ICT use in the classroom. While the first one found that teachers' gender affects the use of ICT in the classroom language teaching and learning practices, the second one found that teacher gender had no significant effect.

Likewise, gender gap has been investigated by few other studies (e.g., Cooper, 2006) revealing mostly indecisive results about the effect of gender on teachers' ICT integration in their classrooms. However, according to Volman and van Eck (2001) with regard to teachers' gender and ICT use, they have reported lower levels of technology use by female teachers due to female teachers' limited technology access, skills, and interest.

Findings from Russel and Bradley's (1997) study, have reported the existence of a connection between gender and levels of ICT anxiety (computer in this case), in which female teachers exhibited a greater degree of anxiety than male teachers. Similarly, Todman (2000) concluded that research on ICT, computer precisely, self-efficacy revealed that males on average acquired computer self-efficacy faster than females. In this regard, significant differences between males and females were observed in terms of technical ICT capabilities and use. In this case, male teachers scored higher than female teachers.

As for the Arab world, in support of the findings above, a study which was conducted by Mahdi \& Al-Dera (2013) about the impact of teachers' age, gender and experience on the use of information and communication technology in EFL teaching at Najran University, Saudi Arabia reported that, among the 46 university teachers who participated in this study, there was a significant difference between male and female teachers in the use of ICT in language teaching and learning. The results showed a lack of ICT training for most of the teachers who participated in the study. The researchers concluded that ICT training courses should be provided to improve ICT integration into EFL language teaching and learning contexts at Saudi universities. They also suggested that female teachers need to receive more 
special training in ICT and technical support in using ICT in their instruction. They added, seminars and workshops by female ICT experts should be provided for in-service female teachers. As for Sadik's (2006) study, its findings revealed that Egyptian male teachers had higher computer experience and more positive computer attitudes than their female counterparts.

In Morocco, Fatmi (2010) explored the "GENIE" Program (a governmental in-service ICT training program in Morocco) in terms of the factors affecting Moroccan EFL teachers' ICT integration in the classroom. One of the major findings of his study, in which 141 Moroccan EFL high school teachers participated, is that gender affects teachers' level of ICT integration in the sense that female teachers are more likely to use computer technology in the classroom than male teachers. This conclusion is supported by findings from Khine's (2001) research which stated that males have less anxiety and more confidence toward the use of computers than females. However, females were reported to have more computer liking and computer usefulness than males, and consequently were more disposed to see the relevance of technology in their teaching.

On the contrary, the results of the above studies are in disagreement with those of other studies which found no differences between male and female teachers in attitude and use of ICT (Gressard \& Loyd, 1986; Kendel, 1995; Loyd \& Gressard, 1984; Poynton, 2005; Roussos, 2007; Shegog, 1997; Woodrow, 1992). A study that was conducted by Poynton (2005), for example, concluded that the common cliché of gender discrepency in terms of ICT integration in teaching started to disappear in the 21st century. Similarly, Dyck and Smither (1994) studied the effect of the factor of gender on teachers' use of ICT in the classroom and found no relationships. Likewise, Loyd and Gressard (1984) did not find gender to be significantly related to computer attitudes. Based on this finding, they stated that "the lack of significant finding related to sex should leave open the possibility that females may be as interested as males in computers, and that females do not necessarily have more anxiety than males about working with computers" (p. 76). In this respect, Rahimi and Yadollahi (2011) conducted a study about ICT use in EFL classes in the Iranian public schools. The study focused on the EFL teachers' characteristics with regard to ICT use. In the light of the evidence from this study which was based on the findings obtained from the 248 Iranian EFL teachers who participated in this survey, no significant correlation was detected between gender and ICT use.

A close examination of the aforementioned studies reveals that the contradictions in the findings may be due to cultural differences, mainly differences in gender roles, between the settings where the studies were conducted. These conflicting results also suggest that more research should be conducted to examine the gender variable in relation to technology integration.

\section{METHOD}

\subsection{Research Design}

To answer the main research question of this study, which is 'Do Moroccan male and female teachers differ in their use of ICT in their classroom instruction?', data was collected and analysed through the mixed methods approach: a combination of quantitative and qualitative methodologies, especially the survey questionnaire and the interviews. The mixed methods design "is used when the strengths of each method offset the weaknesses of the other method so that together they provide a more comprehensive and complete set of data." (McMillan, 2004, p. 289). Mixed methods, then, provide greater credibility in the findings, and provide more complete and more valid results (Creswell, 2003; McMillan, 2004). The 
use of the mixed methods provided rich numerical and narrative data that allowed for a complete understanding of the problem under study. According to Tashakkori and Teddlie (1998), "mixed methods are often more efficient in answering research questions than either the qualitative or the quantitative approach alone" (p. 167). Therefore, a two-phase sequential mixed-methods design was utilized, whereby investigative procedures begin with the quantitative method followed-up by qualitative procedure (Tashakkori \& Teddlie, 1998). The two-phase, sequential mixed methods study is used to acquire statistical, quantitative results from a sample, and then followed up with a few individuals interviewed to qualitatively explore those results in more depth.

The quantitative data results provided the following:

(1) Criteria for the sampling of the teachers to be interviewed,

(2) Criteria for the development of the interview instrument.

The qualitative data from the interviews was used to meet the following objectives:

(1) Complementing the quantitative data from the survey questionnaire,

(2) Contextualizing the quantitative findings,

(3) Confirming the quantitative findings.

To survey all participants in a short time, the questionnaire is used to collect data. The purpose of this study is to explore and understand EFL male and female teachers' level of ICT integration in their classroom practice, that is why a survey questionnaire is the most appropriate way to collect data at one point in time (Creswell, 2002). According to Kopcha and Sullivan (2006), "Survey data based on self-reports of teachers is the most commonly used method to collect information about both the instructional design practices of teachers and their use of computers in instruction" (p. 628).

Qualitative research method is necessary when we want to focus on meaning in context (Merriam, 1998). The reason for utilizing interviews in this study is to increase and deepen the understanding of the Moroccan EFL male and female teachers' level of technology integration in the classroom, the ICT tools they frequently use and prefer and the factors that affect their ICT use in the classroom or, as Ridenour and Newman (2008) put it, "by adding the interviews, a more holistic understanding was possible." (p. 33). The purposes of qualitative research studies are to describe processes and relationships, to interpret phenomena, to verify the validity of theories and generalizations, and to evaluate policies and practices (Leedy \& Ormrod, 2005). In addition to that, qualitative research approach is appropriate when a researcher plans to clarify ideas, develop procedures, and explore issues (Creswell, 2002; Leedy \& Ormrod, 2005).

\subsection{Participants}

The target population of the current study is the Moroccan public secondary school EFL teachers. The population of this study was sampled using convenience sampling methods (Cohen, 1988), also called opportunity sampling, which simply involves choosing the nearest individuals to serve as respondents. Due to the difficulty of accessibility to a larger population of teachers of English from different regions of Morocco, the samples were selected from accessible population (Ary, Jacobs, \& Razavich, 2002). The easily accessible population for sampling was teachers practicing in public secondary schools in the delegations of Agadir Idaoutanane and Inzegane Ait-Meloul, and teachers who participated in the $3^{\text {rd }}$ Morce-Net (Moroccan Resource Centers of English Network) Annual Conference which was held in Agadir from January 26th to January 28th, 2015 who belong to the same delegations abovementioned. The interview sample was selected based on three criteria:

a. Teachers' willingness to be interviewed.

b. Cases that might best illuminate the problem under study, such as teachers who are known to be technology leaders among their colleagues and teachers who are known to be openly against the integration of technology in the classroom. 
c. Gender balance

The use of purposive sampling method helped in the identification of the eight teachers selected for the study. The selected participants in this sample are teachers with varied uses of ICT for instructional purposes, years of teaching experience, age category and gender. The questionnaire was administered to 120 Moroccan public secondary school teachers of English from different schools belonging to both delegations; Agadir Idaoutanane and Inzegane AitMeloul. The return rate was $66.6 \%$, yielding a final sample of 80 teachers. The research sample of this study consisted of 80 respondents to the survey questionnaire, eight teachers agreed to participate in the semi-structured interviews. All the respondents were teachers of English practicing in public secondary schools.

\subsection{Instruments}

The instruments that were used in this study are a survey questionnaire and interviews. The survey results were analysed quantitatively, whereas the interview data were analysed qualitatively.

\section{The survey questionnaire}

The survey questionnaire which was used for this study includes 4 main parts. The items of the survey which were developed in this study were based on (Chen, 2008) with some amendments to reflect the research questions:

(1) Demographics survey, (2) Availability of ICT facilities in the public secondary schools survey, (3) ICT knowledge and skills survey and (4) ICT use in teaching survey (see Table 1 below).

Table 1. The Survey Questionnaire Instrument

\begin{tabular}{ll}
\multicolumn{1}{c}{ Target Data } & \multicolumn{1}{c}{ Instrument } \\
\hline 1. Teachers' demographics & 1.Demographic survey \\
\hline 2.Availability of ICT facilities in schools & $\begin{array}{l}\text { 2.Availability of ICT facilities in } \\
\text { schools survey }\end{array}$ \\
\hline $\begin{array}{l}\text { 3.Teachers' ICT knowledge/skills } \\
\text { 4.Male and female teachers' level of ICT integration } \\
\text { in teaching }\end{array}$ & 3.ICT knowledge and skills survey \\
\hline
\end{tabular}

\section{Demographic survey}

The demographic survey asked questions to get the personal and professional information about the participants in this survey including age, gender, highest educational degree, years of teaching experience, number of teaching hours per week, number of classes assigned to teach per week and pre-service training.

\section{Availability of CT facilities in the public schools survey}

The availability of ICT facilities in public schools survey section asked questions to elicit data about the availability of ICT facilities in the Moroccan public secondary schools which the participants in this survey belong to.

\section{ICT knowledge survey}

The ICT knowledge survey section sought to elicit data about ICT knowledge and skills that the participants in this survey have. The responses to the items of this section were treated as statistical descriptive information that was possibly correlated with teachers' level of ICT integration. 


\section{Level of ICT Integration survey}

The level of ICT integration survey section sought to get data about the level of ICT integration of male and female teachers in teaching.

\section{Validity and credibility of the questionnaire}

One of the main reasons for using a survey questionnaire in this research is that the findings of this study are meant to be generalizable. According to Newman \& Benz (1998), quantitative research using survey questionnaires emphasizes the empirical exploration and explanation of the problem, where generalizability from the sample to the population is the goal. Besides, one of the strengths of quantitative methods is that they produce quantifiable, reliable data that are usually generalizable to a larger population. As for the practical side, Creswell (2002) noted that survey questionnaires provide information about a broad range of topics in a short amount of time. Furthermore, reliability and validity evaluations can be done effectively and easily on questionnaires.

\section{Piloting the questionnaire}

Piloting the survey instruments is a very significant step in every research before collecting data. Piloting the questionnaire helps the researchers identify any issues on the items of the questionnaires that might be ambiguous to the survey participants, and so might negatively affect the data to be collected during the collection procedure. By identifying such problems, the latter must be resolved prior to the use of the questionnaire with a wider sample. Therefore, before the questionnaires were administered, the questionnaire was piloted in two public secondary schools in Inzegane Ait-Meloul delegation; Hassan Alkhayat high school and Faysal Ben Abdelaziz high school. The number of teachers who participated in piloting the questionnaire was 12; 7 male teachers and 5 female teachers. The questionnaire was improved based on the feedback of the participants in the piloting procedure. The following are the main modifications:

- Re-designing the format of the questionnaire to be in the minimum length possible which would be easier for the participants to answer.

- Changing the wording of certain items (questions).

- Adding the information about the mobile phone to the last item of the questionnaire "would you like to participate in the interview that will be conducted soon on the same topic?" was designed with the aim of recruiting volunteers for the follow-up interview.

\section{The interview}

For the sake of triangulation, besides the survey questionnaire, a semi-structured interview was developed for the qualitative part of the study. Specific questions based on the research questions were designed. The interview was used in this study with the objective of exploring aspects which the quantitative data could not address (Creswell, 2003). Besides, interviewing is one of the most common ways of understanding human beings (Lincoln \& Guba, 1985, Merriam, 1998). Semi-structured interviews were conducted to collect qualitative data. The interview questions sought to mainly discuss (a) teachers' pre-service and in-service ICT trainings and (b) teachers' levels of ICT use in the classroom. Probing questions were used to expand on themes developed during the interviews. Participants were also given the opportunity to expand on any of the questions further.

\subsection{Procedures}

\section{Data collection}

For the purpose of answering the research question, two data collection procedures were used: first, a survey questionnaire and interviews with teachers. The survey questionnaire was handed to teachers of English working in the delegations of Agadir Idaoutanane and Inzegane Ait-Meloul,and the completed questionnaires were collected 
personally from individual teachers so as to maximize the response rate. Any incomplete questionnaires were discarded by the researchers. The second procedure of data collection was interviews with 8 selected teachers. Teachers selected for interviews were contacted by phone to arrange a meeting. Interviews were scheduled and completed over the course of 15 days. Each interview lasted approximately 20 minutes and was recorded for the sake of coding and transcription. All interviews followed the semi-structured interview protocol. The interviews were then transcribed for analysis after teachers' consent.

\section{Data analysis}

\section{Survey data analysis}

The questionnaire responses were analysed to investigate the research questions. The demographic analysis used descriptive statistical procedures, such as measures of frequency distributions to provide a profile of the respondents. Descriptive statistical procedures were also used to analyse both the availability of ICT facilities in schools and teachers' ICT knowledge and skills. To analyse the male and female teachers' level of ICT use in teaching, descriptive statistical procedures was used in this regard. However, another type of statistical analysis was also performed and calculated (T-test) to determine whether there was a significant variation between male and female teachers' use of ICT in the classroom (the studied variable here is the participants' gender). Table 2 below details the statistical analysis procedures used to answer the research question.

Table 2. Statistical Analysis Procedures for Research Question

\begin{tabular}{lll}
\hline \multicolumn{1}{c}{ Research question } & Variables & Statistical procedure \\
\hline $\begin{array}{l}\text { Do Moroccan male and } \\
\text { female teachers differ in }\end{array}$ & $\begin{array}{l}\text {-Independent variable: } \\
\text { Demographic characteristics }\end{array}$ & \\
their use of ICT in their & $\begin{array}{l}\text { (Teachers' gender). } \\
\text { classroom instruction? }\end{array}$ & $\bullet$ Dependent variable: \\
& $\begin{array}{l}\text { Teachers' level of ICT } \\
\text { integration in teaching. }\end{array}$ & \\
\hline
\end{tabular}

\section{Interview data analysis}

The interview responses were taped and then carefully transcribed to be used in the data analyses. Content analysis of each individual transcript was conducted by naming, coding, and classifying emerging patterns and themes of data (Patton, 2002). After accomplishing the content analyses phase, a cross-case analysis was conducted by comparing all the analyses to each other, noting developing patterns, and grouping responses from participants. As themes and categories emerged, they were recorded. The goal of the above process was to ensure that the study had trustworthiness, credibility, confirmability and dependability, and transferability, all of which are components of qualitative research (Lincoln \& Guba, 1985).

\section{RESULTS}

\subsection{The Findlings of the Questionnaire Data Analysis}

The research question "do male teachers and female teachers differ in their use of ICT in their instruction?" sought to explore the respondents' level of ICT integration in their classroom practices. To answer this question, descriptive statistics were used including overall means and percentages along with a T-test. The dependent variable in the research question in this study was teachers' level of ICT use in teaching while the independent variable is teachers' gender. According to the survey results, from the 80 respondents who participated in the survey, 41 out of 45 male teachers $(91.1 \%)$ and 30 out of 35 female 
teachers $(85.7 \%)$ stated that they use ICT in teaching. The mean score of ICT use among male teachers is 0.91 whereas it is 0.86 among female teachers (see Figure 1 below).

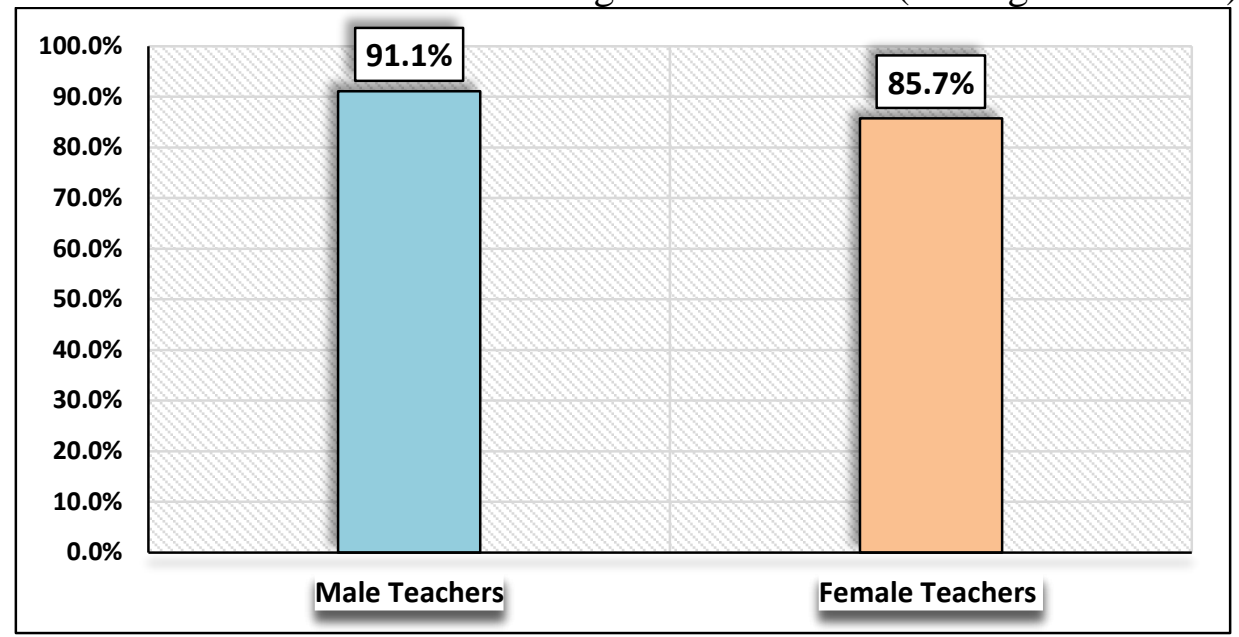

Figure 1. Male and Female Teachers' Level of ICT Use in Teaching

A close look at these results shows that male teachers use ICT in teaching is slightly higher than and female teachers. However, both male and female teachers' level of ICT use is relatively high and similar among the two groups. To explore the research question thoroughly, findings from other survey questions which are relatively related to the finding about level of ICT use by female and male teachers. These surveys were analysed and interpreted to ascertain the possible relationships between the relatively similar level of ICT use among female and male teachers and other factors identified from data findings obtained from other survey questions related to the section of availability of ICT facilities in the schools and respondents' ICT knowledge/skills in the survey questionnaire.

When the respondents were asked whether they own personal computers 44 (98\%) out of 45 male teachers and 34 (97\%) out of 35 female teachers have personal computers. These percentages show that almost $98 \%$ of the teachers from each group own personal computers (see Figure 2 below).

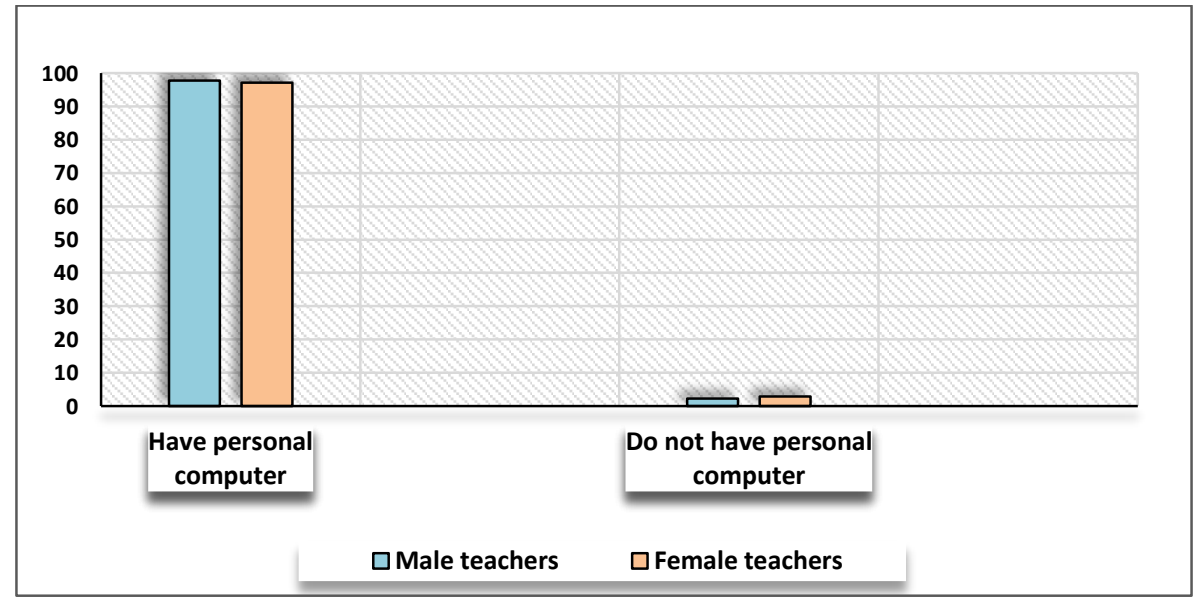

Figure 2. Teachers' Possession of Personal Computers

The eighty respondents were asked whether they have access to the Internet at home. Forty-one (91\%) out of 45 male teacher and 33 (94\%) out of 35 female teachers stated that they have access to the Internet at home. The two percentages are very close indicating that 
the majority of female and male teachers have access to the Internet at home (see Figures 3 below).

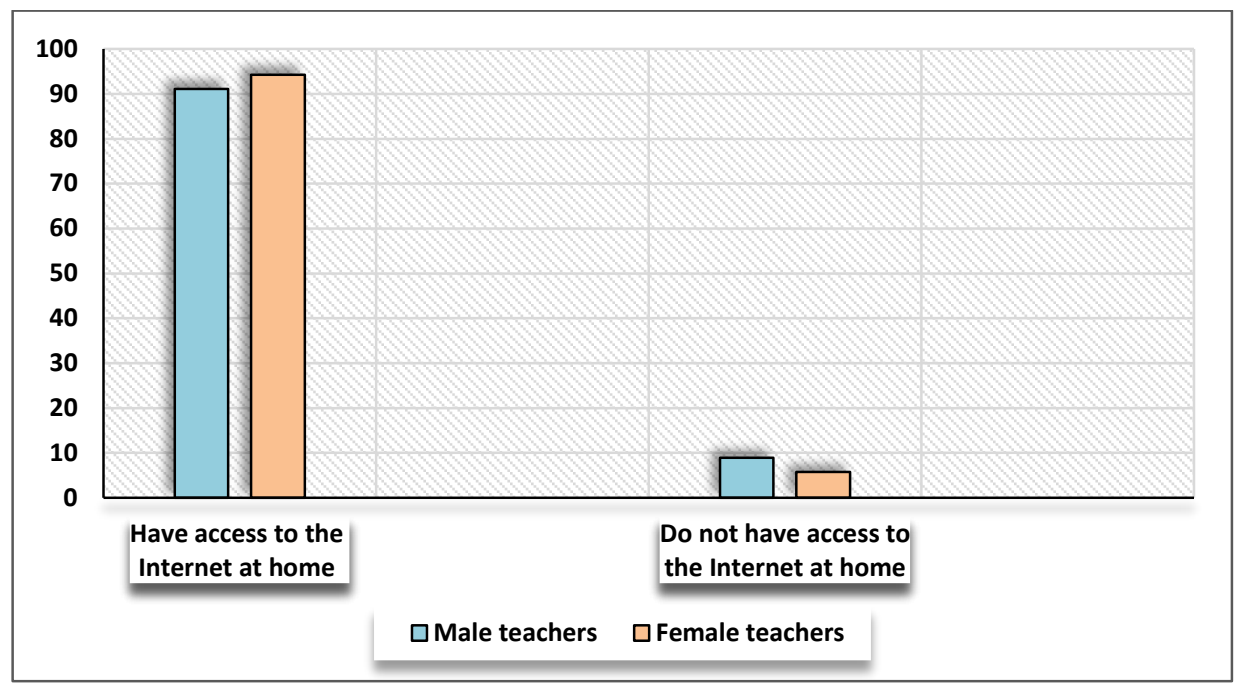

Figure 3. Male and Female Teachers' Access to the Internet at Home

All the female $(n=33)$ and male $(n=41)$ teachers who stated having access to the Internet at home browse the web for getting teaching materials with no exception. Twentyfive $(75.8 \%)$ out of 33 female teachers and $31(75.6 \%)$ out of 41 male teachers browse the internet more than three hours per week to search for teaching materials. These percentages show a similarity in the frequency of web browsing for getting teaching materials among the two groups of male and female teachers (see Figure 4 below).

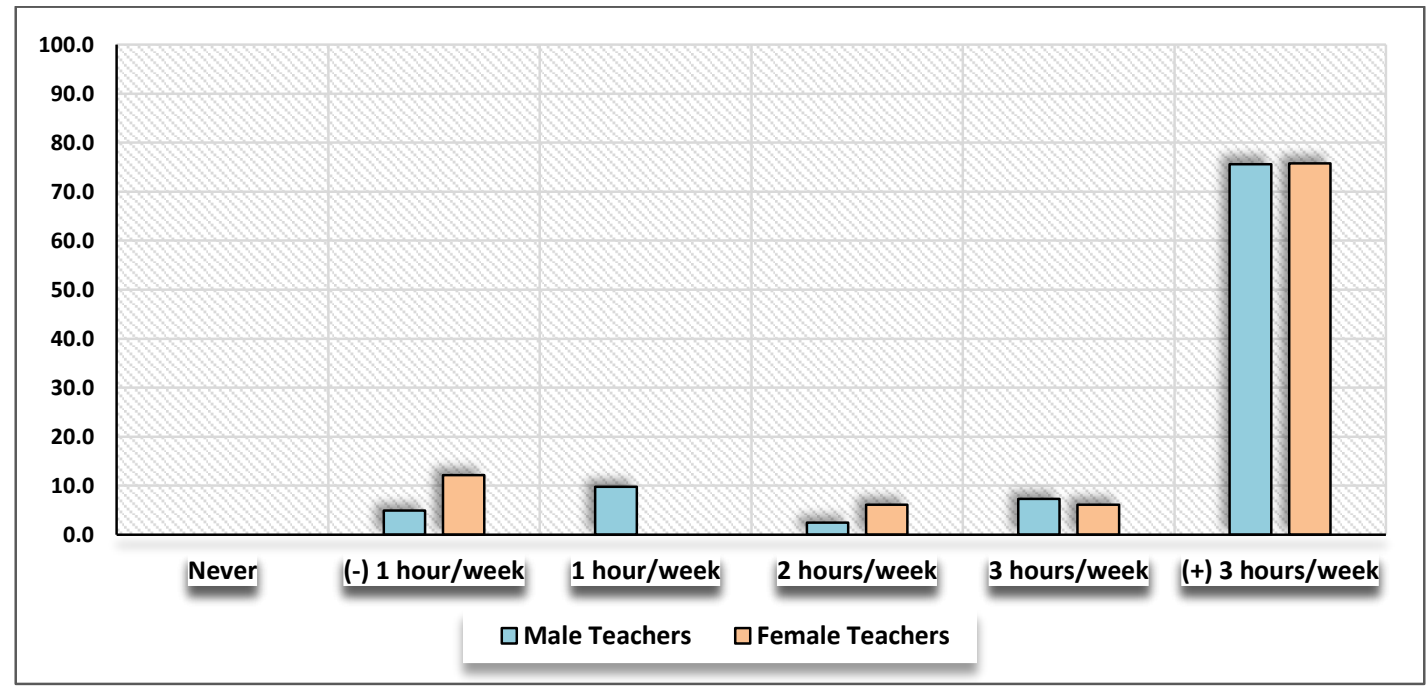

Figure 4. Male and Female Teachers' Web Browse Frequency for Getting Teaching Materials

The eighty survey participants were asked if their school had at least a projector that they can use for teaching. Twenty-nine (83\%) out of 35 female teachers and 39 (87\%) out 45 male teachers stated that they have at least one. This finding indicates that the majority of 
male and female teachers have access to projectors that they can use for teaching in their classrooms (see Figure 5 below).

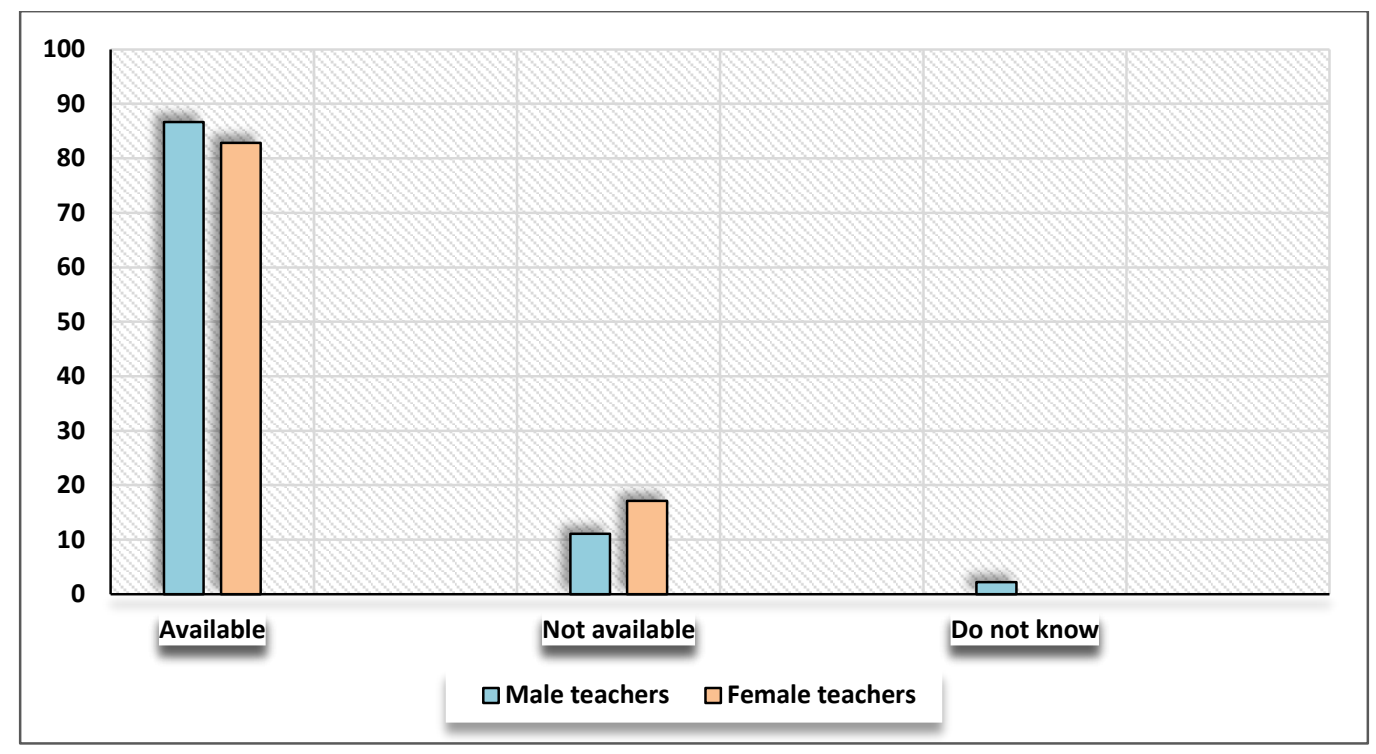

Figure 5. Projector(s) Availability in the Male and Female Teachers' Secondary Schools

$46 \%$ of the female teachers and $42 \%$ of the male teachers have taken training in ICT as part of their pre-service training. These similar percentages among male and female teachers indicate that almost half of the teachers in the male and female groups benefited from ICT training before they started their teaching job (see Figure 6 below).

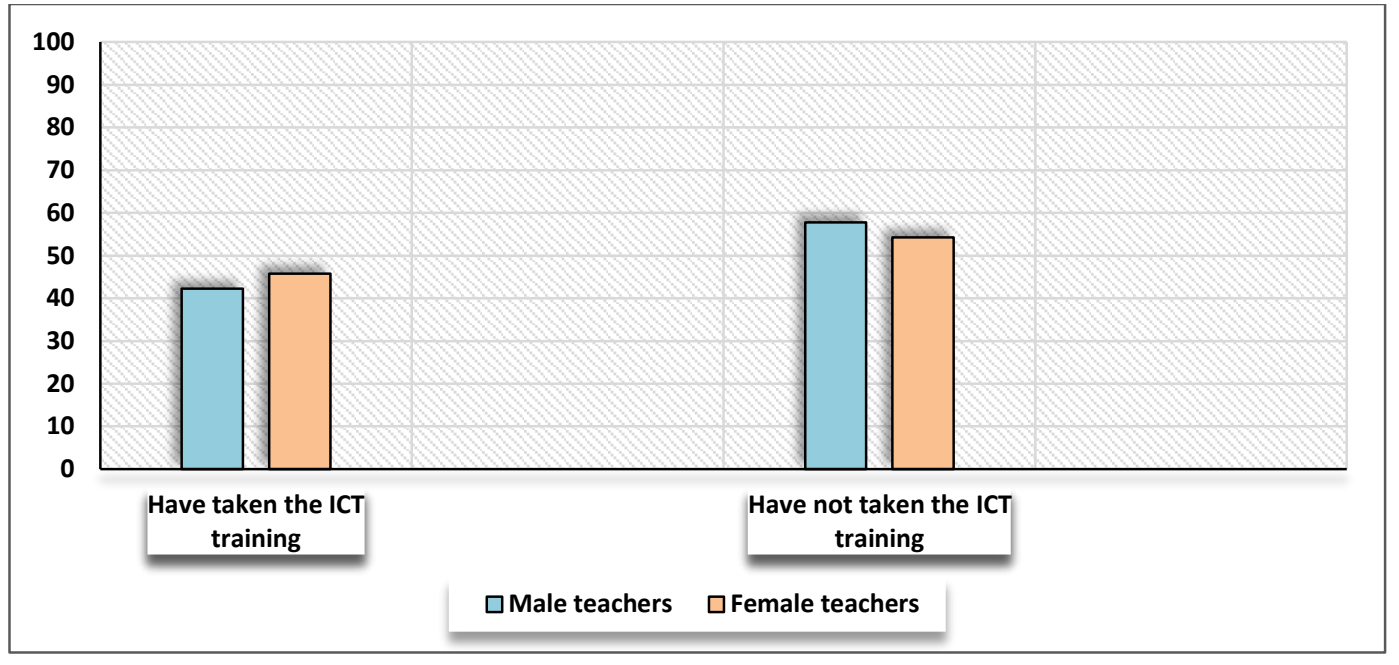

Figure 6. Male and Female Teachers' Pre-service ICT Training

Regarding the GENIE training program, the survey findings shows that the male teachers' group $(42 \%)$ benefited from the GENIE training program as in-service training more than the female teachers' group (34\%). However, these percentages show no big difference between the two groups (see Figure 7 below). 


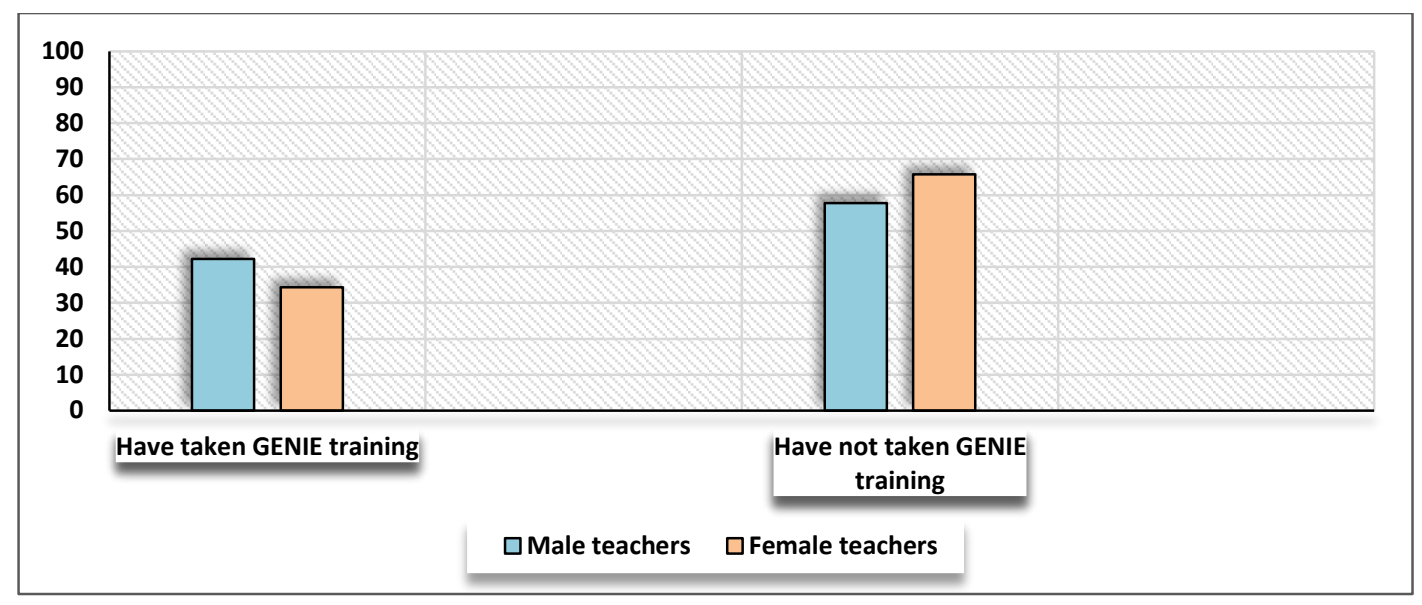

Figure 7. Male and Female Teachers' in-service GENIE Training Program

$77 \%$ of female teachers and $82 \%$ read about ICT, attend ICT seminars, ICT workshops and ICT conferences. Though the survey statistics from the male teachers' group are slightly higher than the female teachers' group, the two percentages remain close and show a very slight difference. This shows that the majority of both female and male teachers are interested in reading about ICT and attending different events about ICT in education (see Figure 8 below).

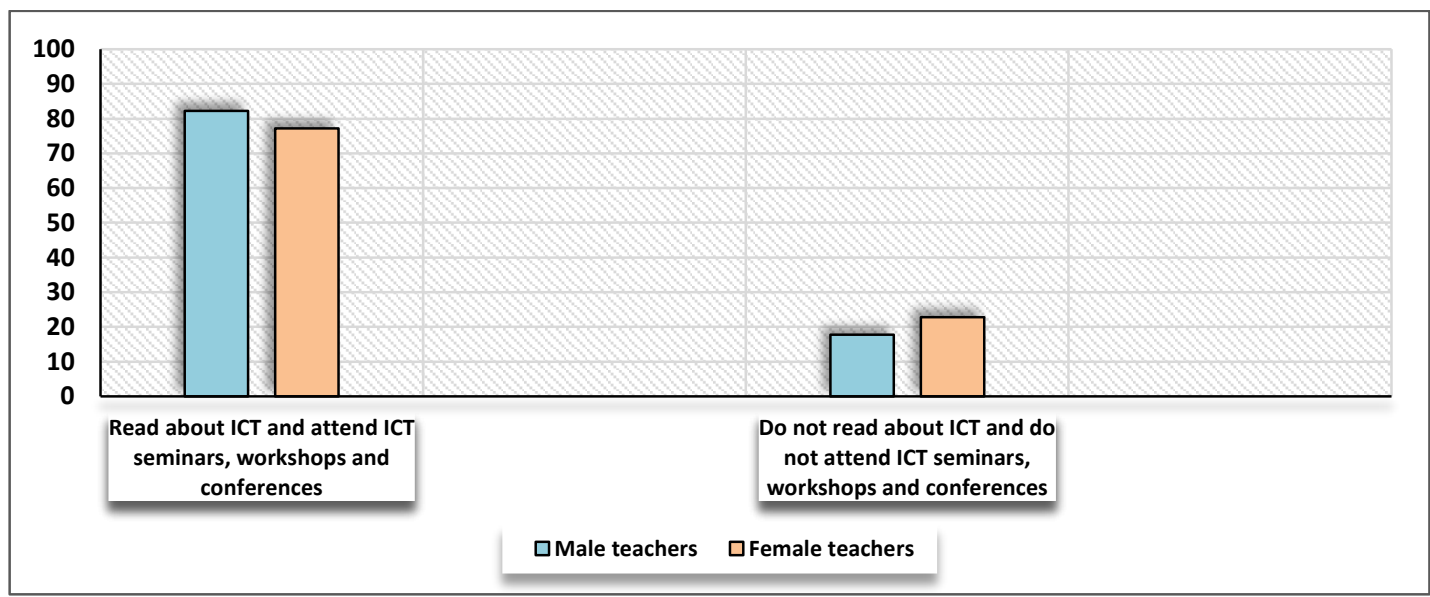

Figure 8. Male and Female Teachers' Responses about ICT Reading, Attending ICT Seminars, Workshops and Conferences

The eighty informants were asked to tick the ICT skills they had to compare the male and female teachers' ICT knowledge. More than $91 \%$ of female and male teachers can start the computer (male teachers and female teachers 100\%), can use search engines (e.g. Google, Yahoo, etc.) (female teachers $100 \%$, male teachers 98\%), can browse the internet (male teachers $100 \%$, female teachers $97.1 \%$ ), can send an e-mail (male teachers $97.8 \%$, female teachers $97.1 \%$ ), can use smart phones/Tablets (male teachers 91.1\%, female teachers $97.1 \%$ ), can use Microsoft Word to type (male teachers $100 \%$, female teachers $94.3 \%$ ) and can operate a printer that is connected to a computer (male teachers $93.3 \%$, female teachers $91.4 \%$ ). In addition, $88.9 \%$ of male teachers and $88.6 \%$ of female teachers can use Power Point and $64.4 \%$ of male teachers and $65.7 \%$ of female teachers can use Web 2.0 tools (e.g. Twitter, WordPress, Weebly, Google Docs, Wordle, ...etc). $84.4 \%$ of male teachers and $80 \%$ 
of female teachers can edit photos and images. These survey statistics show very similar percentages among the two groups as far as the ICT skills mentioned above are concerned.

However, responses from the two groups showed that more male teachers possess more ICT knowledge than female teachers (though the differences are not striking) in the following ICT skills: $84.4 \%$ of male teachers and $77.1 \%$ of female teachers can operate a multimedia projector. $82.2 \%$ of male teachers and $71.4 \%$ can use Microsoft Excel. $82.2 \%$ of male teachers and $71.4 \%$ can use a scanner to copy images. $66.7 \%$ of male teachers and $57.1 \%$ of female teachers can edit videos. $62.2 \%$ of male teachers and $54.3 \%$ can create a personal blog. Almost $50 \%$ of male teachers and $45.7 \%$ of female teachers can create a simple web site. These findings show that the majority of male and female teachers similarly share basic ICT skills which are important for ICT use in teaching. Yet, male teachers have more knowledge about certain ICT skills which could be considered quite sophisticated than female teachers. But generally speaking, as far as ICT knowledge and skills are concerned, the survey findings indicate that there are neither big differences nor extremely different patterns between male and female teachers. These significant findings could explain the very similar level of ICT use in the classroom by male and female teachers (see Figure 9 below).

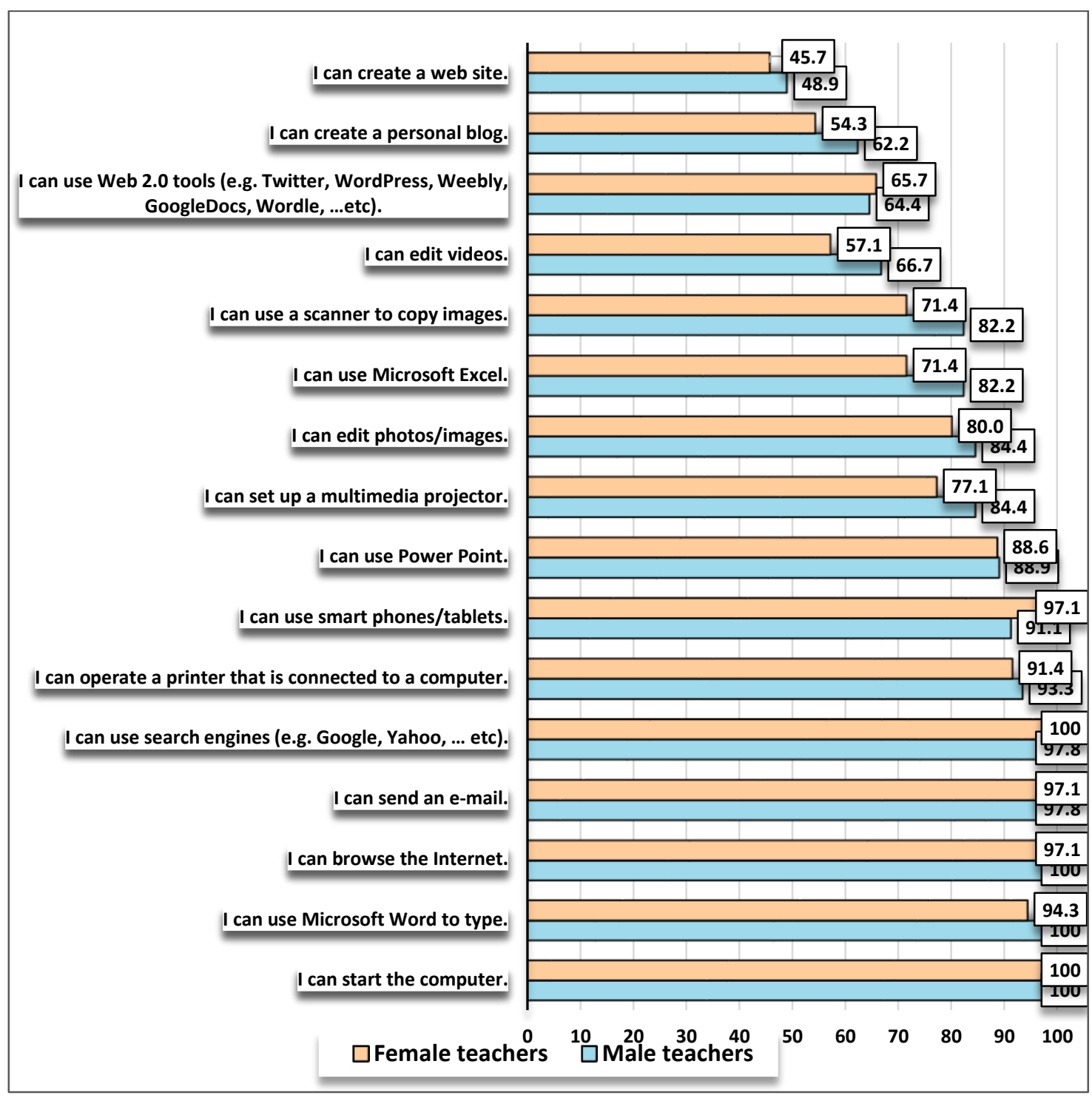

Figure 9. Male and Female Teachers' ICT Skills (percentages) 
Finally, the gender variable was examined to determine whether it affected teachers' level of ICT integration in the classroom instruction. An Independent Samples t-test was conducted to compare male and female teachers' level of technology integration (TLTI) mean scores. These mean differences were checked for statistical significance utilizing a t-test analysis. Although the mean score of male teachers on the TLTI scale $(M=0.91)$ is higher than that of female teachers $(M=0.86)$, the t-test showed no statistically significant difference in scores for both groups $[t \mathrm{P}(\mathrm{T}<=\mathrm{t}) 0.47]$, with the $t$ value at 0.47 and significant at the level 0.05 or less. These results imply that, although male teachers scored higher than female teachers at the level of technology integration, the mean differences were not statistically significant (see Table 3 below).

Table 3. T-test for Gender Differences in Male and Female Teachers' Level of ICT Integration

\begin{tabular}{lcc}
\hline \multicolumn{2}{c}{ t-Test: Two-Sample Assuming Unequal Variances } \\
\hline & Male teachers & Female teachers \\
Mean & 0,91 & 0,85 \\
Variance & 0,08 & 0,12 \\
Observations & 45 & 35 \\
Hypothesized Mean & 0 & \\
Difference & & \\
df & 65 & \\
t Stat & 0,73 \\
P(T<=t) one-tail & 0,23 \\
t Critical one-tail & 1,66 \\
$\mathrm{P}(\mathrm{T}<=\mathrm{t})$ two-tail & $\mathbf{0 , 4 6}$ \\
t Critical two-tail & 1,99 \\
\hline
\end{tabular}

\subsection{The findings of the interview data analysis}

An interview was conducted following administering the survey questionnaire. Eight teachers were invited to participate in face-to-face interviews. The interviews were semistructured using pre-determined questions developed from the guiding questions in the interview protocol. These questions focused on male and female teachers' levels of ICT use in the classroom. Probing questions were used to expand on themes developed during the interview. Participants were also given the opportunity to elaborate further on the questions. The collected qualitative data was useful not only for consolidating and supporting the findings from the survey stage of the study, but also for illuminating some issues that were unanswered by the quantitative data, including the explanation for the reasons why teachers use, do not use or underuse technology in the classroom.

All the eight teachers (Four male and four female teachers) participating in the interview of this study stated that they integrate ICT in their teaching practices in the classroom. Of the four female teachers, three teachers frequently use ICT in the classroom. T2 aged 29 with an eight-year teaching experience stated that she "mostly" integrate ICT in her teaching practices, T7 aged 22 who is a novice teacher ( 1 year of teaching experience) indicated that she uses ICT in the classroom twice a week, and T8 aged 46 who has been teaching for 20 years mentioned that she "often" integrate ICT in the classroom, whereas only one teacher who "rarely" uses ICT in the classroom (T3 aged 32 with a seven-year 
teaching experience). Similarly, three teachers out of the four male teachers stated that they frequently integrate ICT in the classroom teaching practices. T6, with 41 years of age and 14 years of teaching experience, stated that he teaches English using ICT in the classroom on a "daily basis", and T4 aged 41 with a seventeen-year teaching experience mentioned that he "mostly" uses ICT in the classroom, and T1 aged 31 with 8 years of teaching experience revealed that he "sometimes" includes ICT in his classroom teaching practices, whereas T5 aged 31 with a seven-year teaching experience revealed that he "rarely" uses ICT in the classroom. The findings from the answers of the respondents who participated in the interview imply that both male and female teachers' levels of ICT integration in the classroom are very similar both in terms of use and frequency.

\section{DISCUSSION}

\section{Gender and teachers' level of ICT integration}

Regarding the variable of gender, the present study demonstrated that there is no significant difference between male and female teachers' level of ICT use in their classroom teaching practices. More specifically, although male teachers in this study demonstrated possession of more ICT skills and had more integration of ICT in the classroom than female teachers, this study concluded that gender did not affect the level of ICT integration in teaching.

The findings of the present study corroborate the findings of some previous studies. This conclusion is supported by the findings from Dyck and Smither's (1994) research who investigated the repercussion of gender on teachers' integration of ICT in the classroom and found no relationships. They finally concluded that there are no significant differences based on gender and teachers' use and attitudes toward technology. In addition, the findings from the present study agree with Wiburg's (1995) review of the literature in the sense that there are no significant gender differences in computer anxiety and use when both males and females have the same opportunity for training in technology. Likewise, Loyd and Gressard's (1984) study concluded that gender is not significantly related to computer attitudes. Based on this finding, they pointed out that "the lack of significant finding related to sex should leave open the possibility that females may be as interested as males in computers, and that females do not necessarily have more anxiety than males about working with computers" (p. 76). Some other researchers such as Busch (1995) and Guha (2000) have claimed that there is insufficient evidence to affirm any significant correlation between ICT integration in the classroom and gender. Also, Poynton (2005) claimed that the old stereotypic gender divide in terms of ICT integration in teaching is closing in the 21 st century. Another study found that gender did not explain the variance in the value that vocational teachers place on ICT in teaching (Kotrlik, Redmann, \& Douglas, 2003). Finally, Rahimi and Yadollahi's (2011) study which investigated ICT use in the Iranian public school EFL classes with regard to teachers' characteristics, found no significant correlation between gender and teachers' ICT use.

On the other hand, the results of the present study are not consistent with the findings from Volman and van Eck's (2001) research with regard to teachers' gender and ICT use. Their study has reported lower levels of ICT use by female teachers due to female teachers' limited technology access, skills, and interest. This conclusion is supported by findings from Khine's (2001) study which stated that males have less anxiety and more confidence concerning the use of technology for instructional purposes than females. Likewise, Russel and Bradley's (1997) study, found out that there exists of a correlation between gender and levels of ICT anxiety in which female teachers showed a greater degree of anxiety than male teachers. In this respect, Van Braak et al. (2004) found that in addition to attitudes toward technology use in teaching and technology training, gender had the strongest direct effect on ICT use in the classroom. In the same line of thought, Mahdi and Al-Dera's (2013) study 
about the impact of teachers' age, gender and teaching experience on the integration of ICT in EFL classes at Najran University in Saudi Arabia, reported that there is a significant difference between male and female teachers in the use of ICT in language teaching and learning. Similarly, Fatmi's (2012) study which explored the "GENIE" Program in terms of the factors affecting Moroccan EFL teachers' ICT integration in the classroom, concluded that gender affects teachers' level of ICT integration in the sense that female teachers are more likely to use computer technology in the classroom than male teachers.

\section{CONCLUSION}

The purpose of this study is to investigate the Moroccan male and female teachers' level of ICT use in the curriculum. In order to achieve this aim, a mixed-method design was used for it is the most suitable approach to answer the research question, and the most appropriate one that fits the purpose of this study. Questionnaires and interviews were utilized to investigate the Moroccan EFL male and female teachers' level of ICT integration in the classroom. The findings from the analyses of quantitative and qualitative data were in agreement with each other with regard to the research question. Accordingly, quantitative and qualitative data analyses revealed that gender had no effect on the teachers' level of ICT integration in the classroom.

On account of the findings aforementioned, this investigation has several implications for the field of ICT integration in the Moroccan EFL context. The findings of this study generally indicated an interesting level of ICT integration by Moroccan male and female teachers in the EFL classrooms, yet the ICT use should be increased in the Moroccan EFL classroom teaching practices. Although the results of this study indicated that Moroccan male and female EFL teachers' level of ICT use in the classrooms is generally similar, yet as evidenced by other findings of the present study along with a number of previous studies, the majority of teachers often occasionally integrate ICT in the classroom, whereas a very few number of teachers incorporate it in their teaching practices on a daily basis (Becker, 2000; Cuban, 2000). Therefore, educational officials, decision makers, educational planners, supervisors, trainers, administrators and teachers should be aware of the ICT integration contextual factors such as the constraints and barriers that hinder teachers' integration of ICT with the goal of facilitating the process of ICT integration in the schools. Generally, attempts to increase teachers' ICT use begins with encouraging teachers to integrate more ICT into the curriculum by providing more effective trainings on ICT integration as part of teachers' professional development and ICT related resources, and equipping the classrooms with the ICT facilities needed for a daily use. These contextual factors require fundamental change though as reported by the research literature, they have not often been given sufficient attention (Ertmer, 1999). For this reason, the priority of the future initiatives and planning strategies in Morocco should first start by building solid ICT infrastructure at schools, and then provide teachers with ICT training suitable to their teaching conditions.

\section{REFERENCES}

Abu Elenein, A. (2019). The Effect of Utilizing Digital Storytelling on Developing Oral Communication Skills for 5th Grade Students at Rafah Primary Schools. International Journal of Language and Literary Studies, 1(1), 30-46. https://doi.org/10.36892/ijlls.v1i1.24

Ary, D., Jacobs, L. C., \& Razavich, A. (2002). Introduction to research in education (6th ed.). Fort Worth: Harcourt Brace. 
Balanskat, A., Blamire, R., \& Kefala, S. (2006). A review of studies of ICT impact on schools in Europe: European Schoolnet.

Baylor, A. L., and Ritchie, D. (2002). What factors facilitate teacher skill, teacher morale, and perceived student learning in technology-using classrooms? Computers \& Education, 39(4), 395-414.

Bebell, D., Russell, M., \& O'Dwyer, L. (2004). Measuring teachers' technology uses: Why multiple-measures are more revealing. Journal of Research on Technology in Education, 37(1), 45-63.

Becker, H. J. (2000). Access to classroom computers. Communications of the ACM, 43(6), 24 25.

Busch, T. (1995). Gender differences in self-efficacy and attitudes toward computers. Journal of Educational Computing Research, 12, 147-158.

Cancannon, F., Flynn, A., and Campbell, M. (2005). What campus-based students think about the quality and benefits of e-learning? British Journal of Educational Technology 36(3), 501-512.

Chen, Y-L. (2008). A Mixed-method Study of EFL Teachers' Internet Use in Language Instruction. Teaching and Teacher Education, 24, 1015-1028.

Claudia, M., Steil, A., and Todesco, J. (2004). Factors influencing the adoption of the Internet as a teaching tool at foreign language schools. Computers \& Education, 42(4), 353-374.

Cohen, J. W. (1988). Statistical power analysis for the behavioral sciences (2nd ed.). Hillsdale, NJ: Lawrence Erlbaum Associates.

Cooper, J. (2006). The digital divide: The special case of gender. Journal of Computer Assisted Learning, 22(5), 320-334.

Creswell, J. W. (2002). Educational research: Planning, conducting, and evaluating quantitative and qualitative research. Upper Saddle Creek, NJ: Pearson Education.

Creswell, J. W. (2003). Research design: Qualitative, quantitative, and mixed methods approaches. (2nd ed.) Thousand Oaks: Sage.

Cuban, L. (2000). Is spending money on technology worth it? Education Week, 19(24), 42.

De Corte, E., Verschaffel, L., Entwistle, N., \& van Merrienboer, J. (Eds.). (2003). Powerful learning environments: unravelling basic components and dimensions. Oxford: Pergamon/Elsevier.

Dyck, J. L., \& Smither, J. A. (1994). Age difference in computer anxiety: The role of computer experience, gender, and education. Journal of Educational Computer Research, 10, 239248.

Egbert, J., Paulus, T., \& Nakamichi, Y. (2002). The impact of CALL instruction on language classroom technology use: A foundation for rethinking CALL teacher education? Language Learning \& Technology, 6(3), 108-126. Retrieved from http://llt.msu.edu/vol6num3/egbert/default.html

Ertmer, P. (1999). Addressing first-and second-order barriers to change: Strategies for technology integration. Educational Technology research and Development, 47(4), 4761.

Fatmi, H. (2010). The impact of a GENIE training program on teachers' readiness to integrate ICT in the classroom. Paper Presented At the 30th Annual Conference of the Moroccan Association of Teachers of English (MATE), Tetouan, Morocco. 
Fatmi, H. (2012). Factors affecting Moroccan EFL teachers' ICT integration: The case of "GENIE" program. Unpublished doctoral dissertation, University of Moulay Ismail, Meknes, Morocoo.

Granger, C.A., Morbey, M.L., Lotherington, H., Owston, R.D., and Wideman, H.H. (2002). Factors contributing to teachers' successful implementation of IT. Journal of Computer Assisted Learning, 18(4), 480-488. http://dx.doi.org/10.1046/j.02664909.2002.00259.doc.x

Gressard, C. P., \& Loyd, B. H. (1986). Validation studies of a new computer scale. AEDS Journal, 19(4), 295-301.

Guha, S. (2000). Digital linkage: Factors related to elementary grade teachers' usage of computers in classroom instruction. Houston, TX: Research Association for Minority Professors. (ERIC Document Reproduction Service No. ED 438936).

Hubbard, P. (2008). CALL and the Future of Language Teacher Education. CALICO Journal, 25(2), 175-188. Retrieved from https://calico.org/memberBrowse.php?action=article\&id=683

Hermans, R., Tondeur, J. , van Braak, J, and Valcke, M. (2008). The impact of primary school teachers'educational beliefs on the classroom use of computers. Computers \& Education, 51(4), 1499-1509.

Hew, K. F, and Brush, T. (2007). Integrating technology into K-12 teaching and learning: Current knowledge gaps and recommendations for future research. Educational Technology Research and Development, 55(3), 223-252. http://dx.doi.org/10.1007/s11423-006-9022-5

Inan, F. A., and Lowther, D. L. (2010). Factors affecting technology integration in K-12 classrooms: a path model. Education Tech Research Dev, 58(2), 137-154. http://dx.doi.org/10.1007/s11423-009-9132-y

Keengwe, J., Onchwari, G., \& Wachira, P. (2008). Computer Technology Integration and Student Learning: Barriers and Promise. Journal of Science Education and Technology, 17(6), 560-565.

Kendel, M. M. (1995). Computer attitudes and use of public and secondary school teachers in Kentucky. (Doctoral Dissertation, University of Kentucky). ProQuest Digital Dissertations (UMI No. AAT 9523940).

Khine, M. S. (2001). Attitudes toward computers among teacher education students in Brunei Darussalam. International Journal of Instructional Media 28, 147-153.

Kim, J. H., Jung, S. Y., and Lee, W. G. (2008). Design of contents for ICT literacy in-service training of teachers in Korea. Computers \& Education, 51(4), 1683-1706. http://dx.doi.org/10.1016/j.compedu.2008.05.001

Kopcha, T. J., \& Sullivan, H. (2006). Self-preservation bias in surveys of teachers' educational technology practices. Educational Technology Research and Development, 55(6) 627646.

Kotrlik, J. W., Redmann, D. H., \& Douglas, B. B. (2003). Technology integration by agriscience teachers in the teaching/learning process. Journal of Agricultural Education 44(3), 78 - 90.

Leedy, P. D., \& Ormrod, J. E. (2005). Practical research: planning and design (8th ed.). New Jersey: Pearson Merrill Prentice Hall. 
Lim, C. P., Teo, Y. H., Wong, P., Khine, M. S., Chai, C. S., and Divaharan, S. (2003). Creating a conducive learning environment for the effective integration of ICT: Classroom management issues. Journal of Interactive Learning Research, 14(4), 405-423.

Lincoln, Y. S., \& Guba, E. G. (1985). Naturalistic inquiry. Beverly Hills, CA: Sage Publications, Inc.

Loyd, B. H., \& Gressard, C. P. (1984). The effects of sex, age, and computer experience on computer attitudes. AEDS Journal, 18, 67-77.

Mahdi, H. S. \& Al-Dera, A. S. (2013). The impact of teachers' age, gender and experience on the use of information and communication technology in EFL teaching. Canadian Center of Science and Education, 6(6), 57-67. http://dx.doi.org/10.5539/elt.v6n6p57

Mahdizadeh, H., Biemans, H., and Mulder, M. (2008). Determining factors of the use of elearning environments by university teachers. Computers \& Education, 51(1), 142-154.

McMillan, J. H. (2004). Educational research: Fundamentals for the consumer. Boston, MA: Allyn \& Bacon.

Merriam, S. B. (1998). Qualitative research and case study applications in education (Rev.ed.). San Francisco, CA: Jossey-Bass.

Mumtaz, S. (2000). Factors affecting teachers' use of information and communications technology: A review of the literature. Journal of Information Technology for Teacher Education, 9(3), 319-342. Retrieved from http://www.tandfonline.com/doi/abs/10.1080/14759390000200096\#preview

Newman, I., \& Benz, C.R. (1998). Qualitative-Quantitative Research Methodology. Carbondale and Edwardsville: Southern Illinois University Press.

Paraskeva, F., Bouta, H., and Papagianni, A. (2008). Individual characteristics and computer self-efficacy in secondary education teachers to integrate technology in educational practice. Computers \& Education, 50(3), 1084-1091.

Park, C. N., \& Son, J. (2009). Implementing computer-assisted language learning in the EFL classroom: Teachers' perceptions and perspectives. International Journal of Pedagogies and Learning, 5(2), 80-101. http://dx.doi.org/10.5172/ijpl.5.2.80

Patton, M. Q. (2002). Qualitative research \& evaluation methods (3rd ed.). Thousand Oaks, CA: Sage Publications.

Poynton, T.A. (2005). Computer literacy across the lifespan: A review with implications for educators. Computers in Human Behavior, 21(6), 861-872. http://dx.doi.org/10.1016/j.chb.2004.03.004

Rahimi, M. \& Yadollahi, S. (2011). ICT use in EFL classes: A focus on EFL teachers' characteristics. World Journal of English Language, 1(2), 17-29. http://dx.doi.org/10.5430/wjel.v1n2p17

Ridenour C. S., \& Newman, I. (2008). Mixed methods research: Exploring the interactive continuum. Carbondale, IL: Southern Illinois University Press.

Robinson, W. I. (2003). External, and internal factors which predict teachers' computer usage in K-12 classrooms. Detroit, MI: Wayne State University.

Roussos, P. (2007). The Greek computer attitude scale: construction and assessment of psychometric properties. Computers in Human Behavior, 23(1), 578-590. 
Russell, G., \& Bradley, G. (1997). Teachers' computer anxiety: Implications for professional development. Education and Information Technologies, 2(1), 17-30. http://dx.doi.org/10.1023/A:1018680322904

Sadik, A. (2006). Factors influencing teachers' attitudes toward personal use and school use of computers: New evidence from a developing nation. Evaluation Review, 30, 86 - 113.

Shegog, B. F. (1997). An investigation of the relationship between characteristics of teachers and their attitude toward technology integration in their courses. (Doctoral dissertation, Nova Southern University, 1997), ProQuest Digital Dissertations (UMI No. AAT 9908016).

Tashakkori, A., \& Teddlie, C. (1998). Mixed methodology: Combining qualitative and quantitative approaches. Thousand Oaks, CA: Sage Publishers.

Teo, T. (2008). Pre-service teachers' attitudes towards computer use: A Singapore survey. Australian Journal of Educational Technology, 24(4), 413-424.

Todman, J. (2000). Gender differences in computer anxiety among university entrants since 1992. Computers \& Education, 34(1), 27-35.

Van Braak, J., Tondeur, J., \& Valcke, M. (2004). Explaining different types of computer use among primary school teachers. European Journal of Psychology of Education, 19(4), 407-422.

Van Damme, G. (n.d.). (2003). ICT in Practice for Physical Education \& Sports. Retrieved July 20, 2006 from http://www.sportsmedia.org/Sporttapolisnewsletter5.htm

Volman, M. and van Eck, E. (2001). Gender equity and information technology in education: The second decade. Review of Educational Research, 71(4), 613-634. http://dx.doi.org/10.3102/00346543071004613

Wiburg, K. (1995). Gender issues, personal characteristics, and computing. Computing Teacher, 22(4). 7-10.

Wiersma, W. (1995). Research methods in education: An introduction (6th ed). Boston: Allyn and Bacon.

Woodrow, J. E. J. (1992). Locus of control and student teacher computer attitudes. Computers \& Education, 14(5), 421-432.

Yaghi, H. M. (2001). Subject matter as a factor in educational computing by teachers in international settings. Journal of Educational Computing Research, 24(2), 139-154. 